\title{
Improve the Flash Flood Early Warning System in the North-Eastern Parts of Bangladesh
}

\author{
Anik Pal ${ }^{1}$, Mohammad Jakariya ${ }^{1}$, Mohammad Abdur Rahman ${ }^{2}$, Munjira Yeasmin ${ }^{2}$ \\ ${ }^{1}$ Department of Environmental Science and Management, North South University, Dhaka, Bangladesh \\ ${ }^{2}$ Department of Environmental Science, Bangladesh Agricultural University, Mymensingh, Bangladesh
}

Email address:

anik_pal11@yahoo.com(A. Pal), jakariya2009@gmail.com(M. Jakariya),arparag93@gmail.com (M. A. Rahman), ashamoni1102@gmail.com (M. Yeasmin)

\section{To cite this article:}

Anik Pal, Mohammad Jakariya, Mohammad Abdur Rahman, Munjira Yeasmin. Improve the Flash Flood Early Warning System in the NorthEastern Parts of Bangladesh. American Journal of Biological and Environmental Statistics. Vol. 4, No. 3, 2018, pp. 91-97.

doi: 10.11648/j.ajbes.20180403.12

Received: August 29, 2018; Accepted: September 18, 2018; Published: October 27, 2018

\begin{abstract}
This study investigates to improve the flash flood early warning system in the north-eastern parts of Bangladesh. Flash Flood is a major problem and is increasing day-by-day in the north-eastern parts of Bangladesh. The huge amount of economic and life losses every year due to these floods demands for an up to date warning system which will able to notify general peoples of the affected areas. Primary data is collected from the study (Kamalganj, Maulovibazar) which are mostly vulnerable during the flash flood season. Secondary data is collected by performing reconnaissance survey and Focus Group Discussion (FGD). From the survey about 67\% respondents complained that their personal property damage by flash flood, more than $87 \%$ people claimed about the life loss of human and other animals. About $100 \%$ people claimed that there has no any warning system in this region as well as $79 \%$ said about negative to awareness program and at least $83 \%$ respondents demanded about the warning system technology development. Most of the people in this region use mobile phone which can be used as an effective tool by integrating them in a flash flood early warning system. So, this study developed a warning device which is able to send warning through SMS when the water exceeds the normal level measured by a sensor. There was implemented the demo device to identity its efficiency. The device was found to be working accordingly. Some feedbacks were collected from respondents and professionals on the device and their thoughts on implementing this kind of device in their respective areas. The results were positive and research team observed positive response from the respondents as well. This result suggests future research is needed to develop advanced warning system that is able to provide warnings to the affected people covering more areas affected with flash flood.
\end{abstract}

Keywords: Flash Flood, Vulnerability, Early Warning System, Bangladesh

\section{Introduction}

Bangladesh is situated at the lower part of three large alluvial river basins (the Ganges, the Brahmaputra and the Meghna) that includes 57 trans-national rivers and a total upstream catchment area of 1.7 million $\mathrm{km}^{2}$ [1]. These numerous tributaries of the rivers and extensive floodplains combined with high rainfall result in one-fifth to one-third of the country being flooded during the monsoon [2]. These frequent floods and flash floods make the country most vulnerable to natural disaster in the world [3]. Flash floods are a recurrent and hazardous phenomenon in the north eastern part of Bangladesh, agriculturally dominated districts, positioning this agricultural sector at significant risk [4] and flooding due to heavy rainfall results in massive loss of life and property. All the natural hazards capable of producing a disaster, floods are the most common phenomenon that causes human suffering, inconvenience and widespread damage to buildings, structures, crops and infrastructures in Bangladesh [5]. The trend of major flood and the losses have increased drastically in recent years. Floods are so frequent that enough to consider as annual event [6]. In Bangladesh 
most of the people die during floods just because of the lack of weather information in advance [7]. Flood control through structural measures in Bangladesh is impossible due to limited resources but can be reduced the impact through implement early warning system or awareness program [8].

An effective flood early warning system, as a disaster risk reduction (DRR) initiative, can promote both national and local level disaster resilience to flooding, by saving lives and reducing livelihood losses [9]. There is a well-functioning flood forecasting system in Bangladesh, led by the Flood Forecasting Warning Centre (FFWC) and the framework for a national flash flood early warning system is embedded within [8]. Though FFWC is well equipped with short and medium range riverine flood forecasts, the capacity to produce flash flood forecasts is still under development and has been recognized as high priority [10]. Communication and dissemination of warning information is one of the four key elements of a people centered early warning system, along with risk knowledge, monitoring and warning and response capability [11]. The success of a flood early warning system has been argued to largely depend on warning communication being effective [12] but that communication is not strong in Bangladesh. Communication to local communities is highly challenging, particularly in flash flood areas where the available lead time is at a premium. The strong penetration of mobile services in Bangladesh, $66 \%$ of the population [13], offers huge opportunities to enhance this communication component, though to date such services have been under-utilized. The people of flash flood areas have no idea about the early warning system and that's why they suffered so much.

The purpose of this study is to develop a simple early warning device on the basis of people's perception and ensure them about the evacuation time as well as reduce impact on property or lives.

\section{Materials and Methods}

\subsection{Location of the Study Area}

Kamalganj sub-district of Maulovibazar district in northeastern part of Bangladesh is selected as the study area for its own climatic and geographical pattern (Figure 1). In this area, the maximum and minimum temperature varies from $33.2{ }^{\circ} \mathrm{C}$ to $13.6{ }^{\circ} \mathrm{C}$ and the annual average rainfall is 3334 $\mathrm{mm}$. The sub-district occupies an area of $485.26 \mathrm{sq} . \mathrm{km}$. including 112.65 sq. $\mathrm{km}$ forest area. It is located between $24^{\circ} 08^{\prime}$ and $24^{\circ} 29^{\prime}$ north latitudes and between $91^{\circ} 45^{\prime}$ and $91^{\circ} 57^{\prime}$ east longitudes. The sub-district is bounded on the north by Rajnagar sub-district, on the east by Kulaura subdistrict and India, on the south by India and on the west by Sreemangal and Maulavibazar sadar sub-district. The subdistrict has only one river named Dhalai [1]. This area is the mostly affected and suffering by flash flood which flow come from the Indian hilly regions.

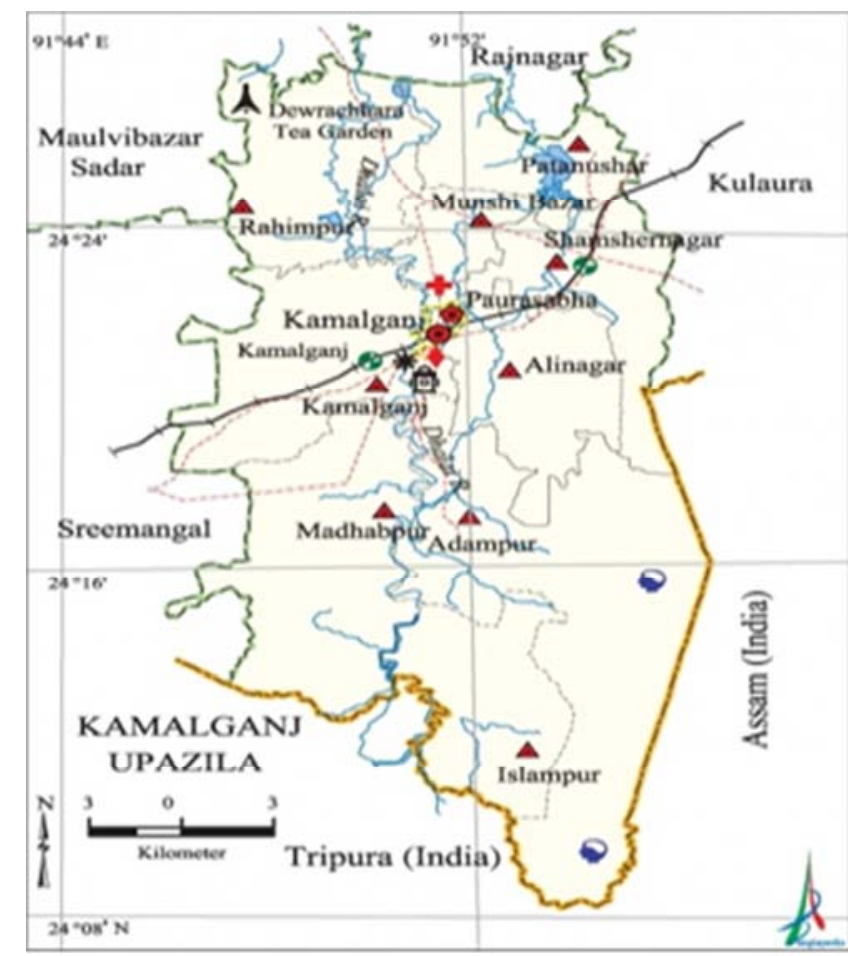

Figure 1. Map showing the study area (Kamalganj sub-district) [1].

\subsection{Data Collection and Socio Economic Information}

The main purpose of this research was to improve the flash flood early warning system. To conducted the fulfil objectives of the study structured questionnaire was prepared and then 100 (300 respondents) households-level questionnaire surveys were conducted into Kamalganj subdistrict under Maulovibazar district with considering respondents' age, education, occupation, gender and their farm size. This union was selected because Dhalai River is near about where the flash flood comes. Two focus group discussions (FGD) were conducted to investigate the reasons behind the flash flood and to identify opinion to cope with flash flood for betterment. Some secondary data were collected from different sources such as, Local Government Engineering Department (LGED), Bangladesh Bureau of Statistics (BBS), Bangladesh Water Development Board (BWDB), Disaster Management Bureau (DMB), journals, reports, research papers, searching websites from Google, and others published and unpublished documents of Government and Non-government Office.

\section{Results and Discussion}

\subsection{Social and Flash Flood Related Survey}

\subsubsection{Flash Flood Scenario}

In the field survey about $88 \%$ people have their no idea about flash flood because they are not educated enough. Maximum numbers of people just can read \& write. This type of disaster they called it 'Bonna'. But some educated person shares about their idea to construct river dam, develop warning system etc. So, it is clear that educational 
qualification plays a very important role in developing knowledge about flash flood early warning system.

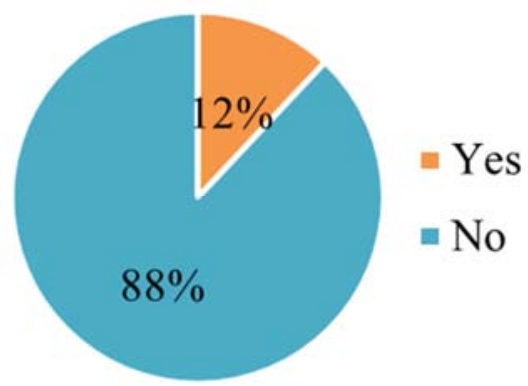

Figure 2. Flash flood related idea of the respondents.

\subsubsection{Yearly Flash Flood Frequency.}

About 50\% people expressed their opinion above 4 times in a year flash flood occurs. But about $33 \%$ and $17 \%$ people said that according to 3-4 times, 2-3 times in a year. So, it is huge problem in this area. As these events are occurring frequently, early warning system is an immediate need in these areas.

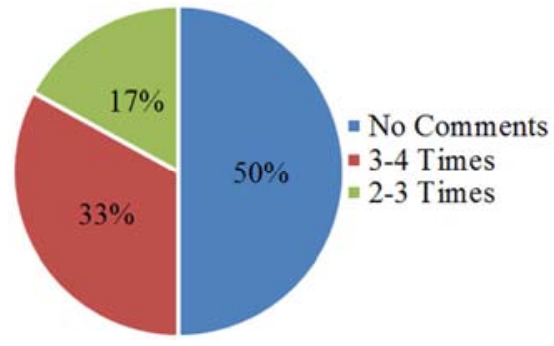

Figure 3. Flash flood occurrence on this area in a year.

\subsubsection{Impact on the Community}

In the survey result about $21 \%$ people said that Government property like road, infrastructure etc. are damages. Almost $12 \%$ people said that financial damage like jobless situation, financial crisis etc. is created in this time. But about $67 \%$ people expressed their opinion to damages their personal property like house, agricultural land damage etc. As these floods causes a great amount of financial damages, proper preparedness is needed to decrease these losses. An early warning system can improve the preparedness measures.

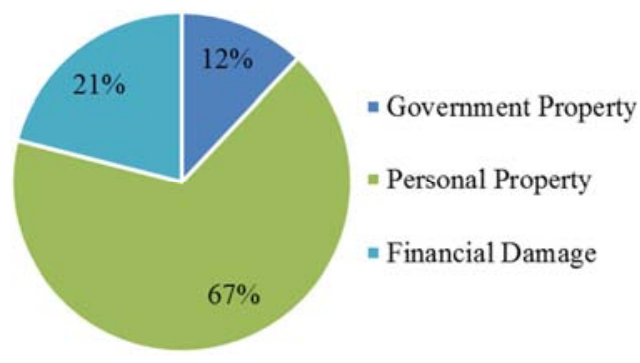

Figure 4. Damage condition during flash flood.

\subsubsection{Life Losses in the Related Area}

In the field survey about $87 \%$ people said that no life losses during flash flood. Another $13 \%$ people said sometimes excessive speed of flash flood to lose some people, animal and other living things. Besides after flash flood various types of diseases like cholera, diarrhea, typhoid, dysentery, fever etc.

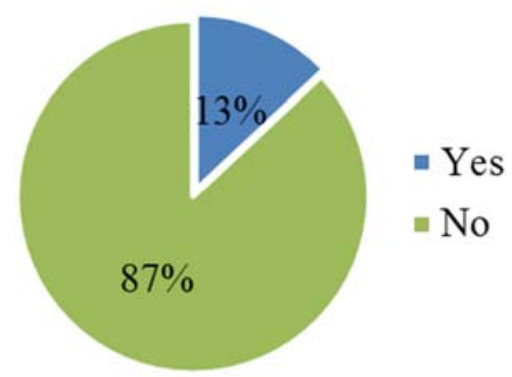

Figure 5. Life losses perception about respondents.

\subsubsection{Early Warning System}

Almost every respondent said that no early warning system for flash flood in the region. So, it is very essential to develop a warning system for their better life and as well as to reduce some damage.

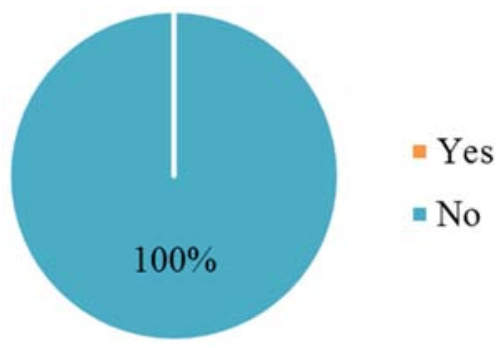

Figure 6. Warning system perception about respondents.

\subsubsection{Awareness Program}

About $79 \%$ people said that there is no awareness program in this region. Besides $21 \%$ people said that some NGOs arrange some program to aware the people. To reduce damage sometimes government should take proper training program to conscious about flash flood.

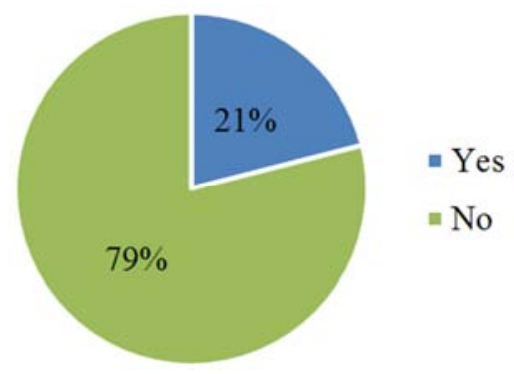

Figure 7. Perception about awareness program.

\subsubsection{People's Perception on Early Warning Technology}

More than $80 \%$ people of this region demanded that they need a comprehensive early warning or forecasting system which could help to save from the flash floods. The people said that mobile oriented early warning device can be helpful to solve the problem or give time to evacuation. 


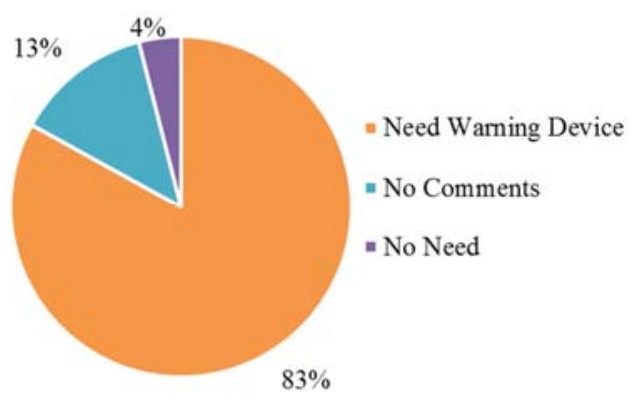

Figure 8. Peoples ' perception on early warning technology.

\subsection{Technical Work Out and Instrumentation}

\subsubsection{Development of the Device}

For the survey result we have to identify that appropriate warning system is needed for this region because of no warning system are existing to warn the people. To develop a warning device, we have to plan these details are given bellow.

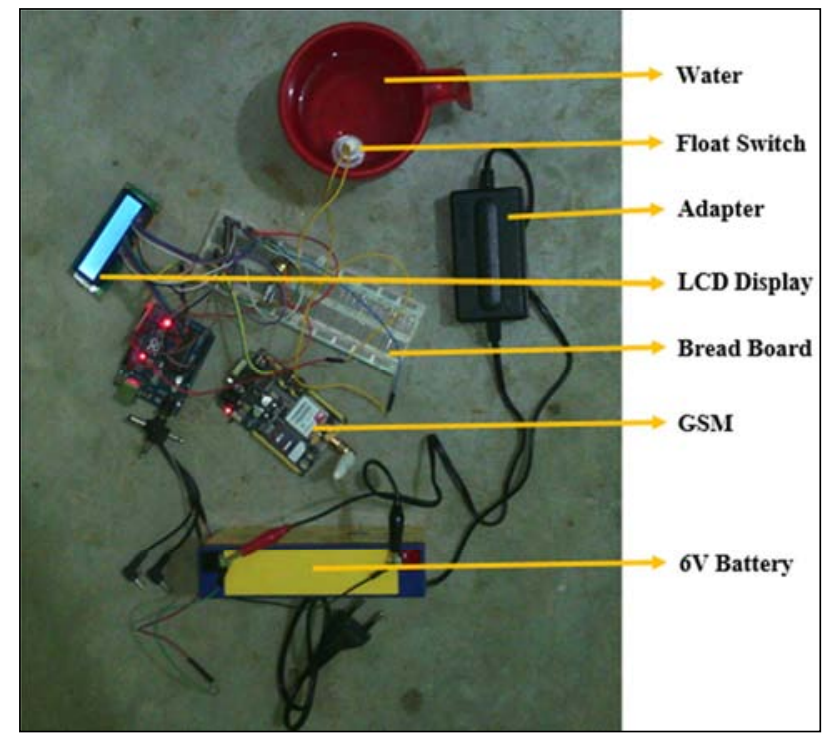

Figure 9. Different components of the device.

\subsubsection{Operation of the Device}

Working Procedure of this project is very simple by using Ultrasonic sensor module which sends the sound waves in the water tank and detects reflection of sound waves that is ECHO. First of all, there need to trigger the ultrasonic sensor module to transmit signal by using Arduino and then wait to receive ECHO. Arduino reads the time between triggering and received ECHO. It is known that speed of sound is around $340 \mathrm{~ms}-1$. So, the calculation of distance can be done by using given formula:

$$
\mathrm{D}=\mathrm{T} / 2 * \mathrm{~S}
$$

In formula (1).

$\mathrm{D}=$ Distance.

$\mathrm{T}=$ Travel Time.

$\mathrm{S}=$ Speed of Sound.

Where the speed of sound is approximately $340 \mathrm{~ms}-1$. By using formula (1), distance from sensor to water surface are easily obtained. After that, its need to calculate water level and water level distances will be determined. Now, water level is fixed by manually. When water level exceeds the fixed water level then GSM can get a signal and GSM make a call/SMS to the Authorized person Phone number. Also LED and alarm on.

\subsubsection{Components}

Arduino Uno (Micro Controller).

Ultrasonic Sensor Module.

16x2 LCD (Display).

GSM (Global System for Mobile Communication)

Module.

Project Board.

Copper Wire.

6 Volt Battery or 12 Volt Adaptor.

Connecting Wires.

\subsubsection{Flow Diagram of Elements}

Ultrasonic Module is used for reposing any event that not normal and this device provide signal to Arduino Uno. The signal is transmitted to the LED device then make alarm. Also, the device provide signal to GSM for mobile application. Besides, Arduino Uno also make signal to LCD display.

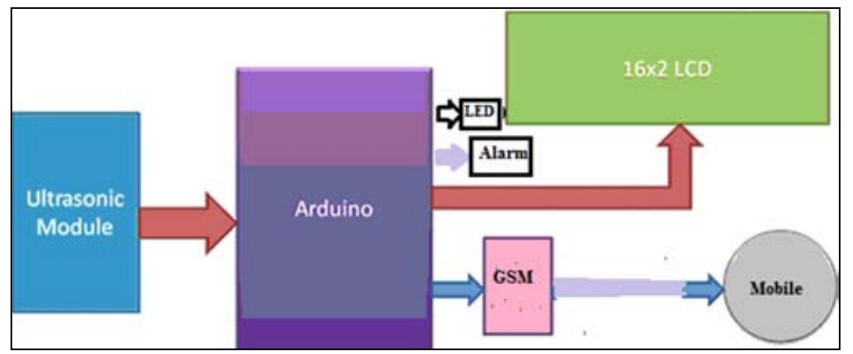

Figure 10. Flow diagram of warning device.

\subsubsection{Total Mechanism in a View}

Arduino Uno (Micro Controller): The Arduino Uno is a microcontroller board based on the ATmega328 (datasheet). It has 14 digital input/output pins (of which 6 can be used as PWM outputs), 6 analog inputs, a $16 \mathrm{MHz}$ ceramic resonator, a USB connection, a power jack, an ICSP header, and a reset button. It contains everything needed to support the microcontroller; simply connect it to a computer with a USB cable or power it with an AC-to-DC adapter or battery to get started.

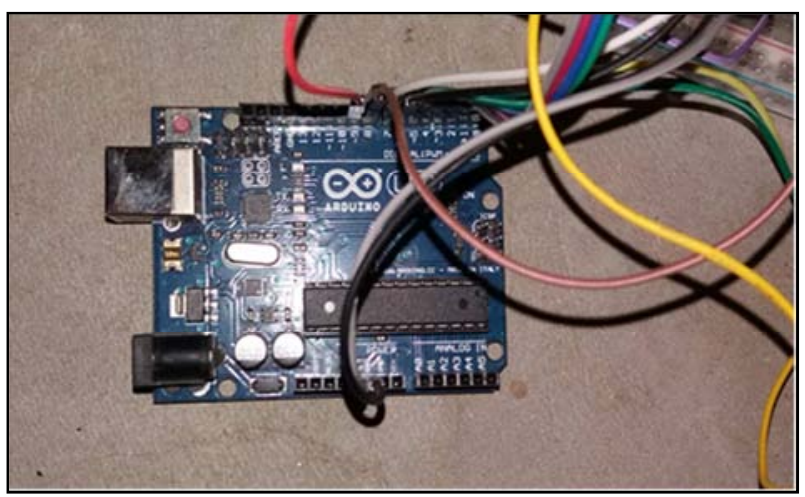

Figure 11. Arduino Uno (Micro Controller). 
Bread Board: A breadboard is used to make up temporary circuits for testing or to try out an idea. No soldering is required so it is easy to change connections and replace components. Parts are not damaged and can be re-used afterwards. Breadboards have many tiny sockets (called 'holes') arranged on a $0.1 "$ grid. The leads of most components can be pushed straight into the holes. ICs are inserted across the central gap with their notch or dot to the left. Wire links can be made with single-core plastic-coated wire of $0.6 \mathrm{~mm}$ diameter (the standard size), this is known as $1 / 0.6 \mathrm{~mm}$ wire.

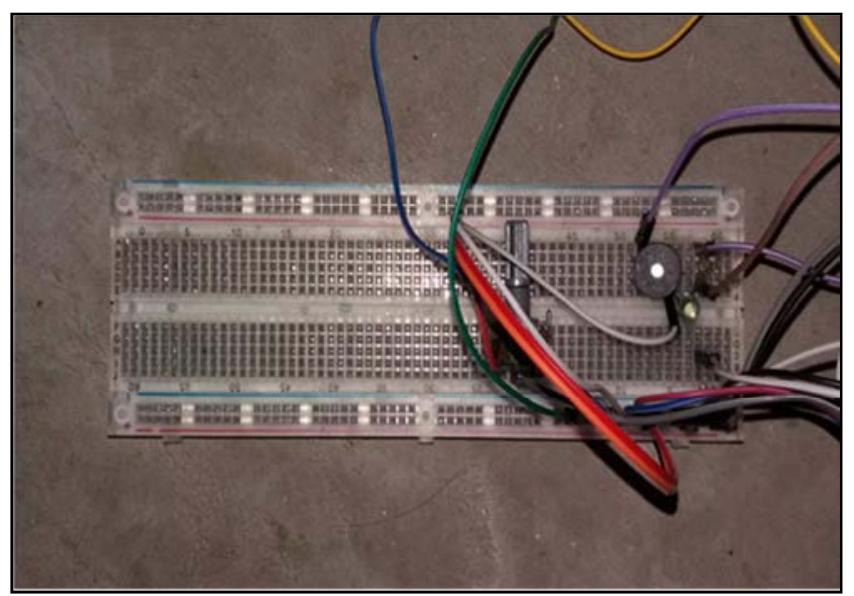

Figure 12. Bread Board.

GSM (Global System for Mobile Communication): The Global System for Mobile Communications (GSM) system is a widely deployed digital mobile telephony standard. The GSM standard leverages a variant of TDMA (time division multiple access) and is the most deployed of the three competing legacy digital wireless technologies on the market today (GSM, TDMA, and CDMA). The GSM standard works by first digitizing and then compressing information. Once compressed, the data is transmitted on a channel along with two additional streams of user information that are located in individual time slots. GSM operates in the 900 $\mathrm{MHz}$ or $1800 \mathrm{MHz}$ frequency bands.

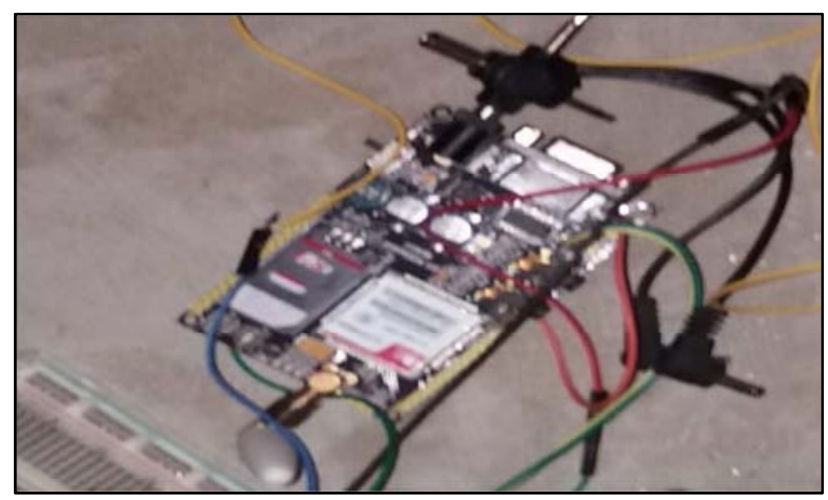

Figure 13. GSM (Global System for Mobile Communication).

LCD Display: LCD (liquid crystal display) is the technology used for displays in notebook and other smaller computers. Like light-emitting diode (LED) and gas-plasma technologies, LCDs allow displays to be much thinner than cathode ray tube (CRT) technology. LCDs consume much less power than LED and gas-display displays because they work on the principle of blocking light rather than emitting it. An LCD is made with either a passive matrix or an active matrix display grid. The active matrix LCD is also known as a thin film transistor (TFT) display. The passive matrix LCD has a grid of conductors with pixels located at each intersection in the grid. A current is sent across two conductors on the grid to control the light for any pixel. An active matrix has a transistor located at each pixel intersection, requiring less current to control the luminance of a pixel.

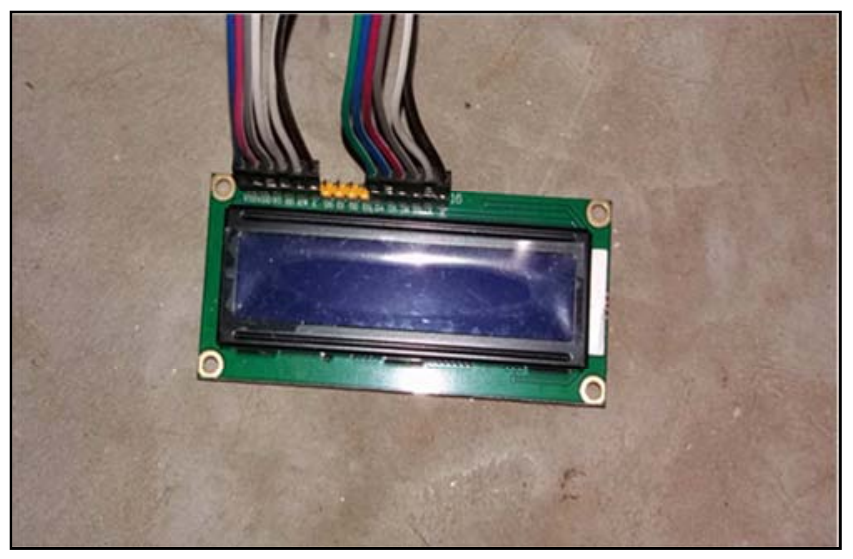

Figure 14. LCD Display.

Float Switch: A float switch is a type of level sensor, a device used to detect the level of liquid within a tank. The switch may be used to control a pump, as an indicator, an alarm, or to control other devices. One type of float switch uses a mercury switch inside a hinged float. Another common type is a float that raises a rod to actuates a microswitch. One pattern uses a reed switch mounted in a tube; a float, containing a magnet, surrounds the tube and is guided by it. When the float raises the magnet to the reed switch, it closes. Several reeds can be mounted in the tube for different level indications by one assembly [14].

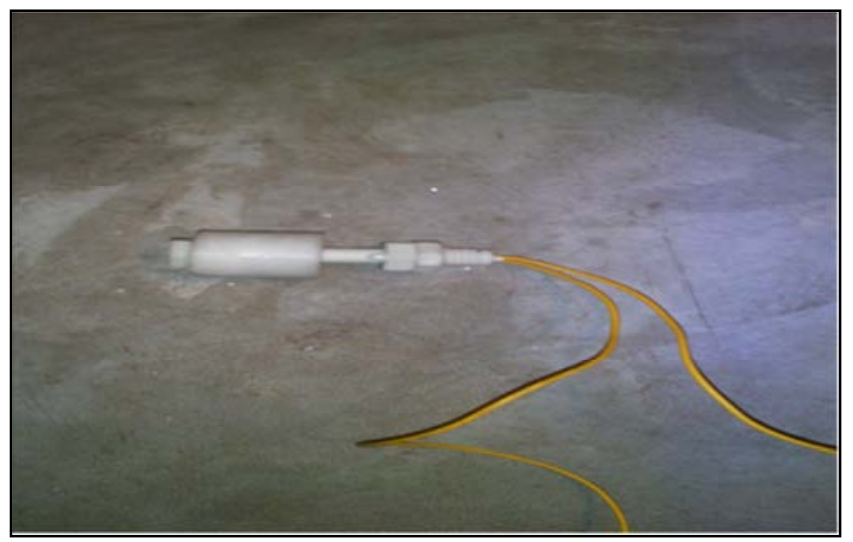

Figure 15. Floating Switch. 
Rechargeable Battery: A rechargeable battery, storage battery, secondary cell, or accumulator is a type of electrical battery which can be charged, discharged into a load, and recharged many times, as opposed to a disposable or primary battery, which is supplied fully charged and discarded after use. It is composed of one or more electrochemical cells. The term "accumulator" is used as it accumulates and stores energy through a reversible electrochemical reaction. Rechargeable batteries are produced in many different shapes and sizes, ranging from button cells to megawatt systems connected to stabilize an electrical distribution network. Several different combinations of electrode materials and electrolytes are used, including lead-acid, nickel-cadmium (NiCd), nickel-metal hydride (NiMH), lithium-ion (Li-ion), and lithium-ion polymer (Li-ion polymer) [15].

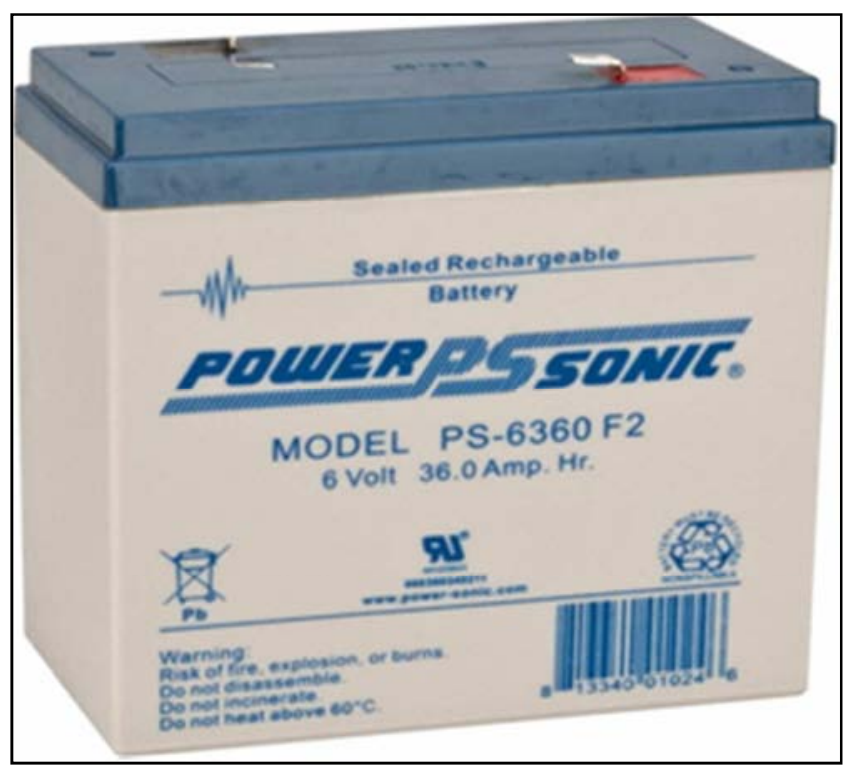

Figure 16. 6 Volt Rechargeable Battery.

Total Elements Engagement: The scattered elements are sincerely engaged with one another and prepared for demonstration. Whole device was worked together properly. By following the block diagram the setup was done properly for application and experimentation.

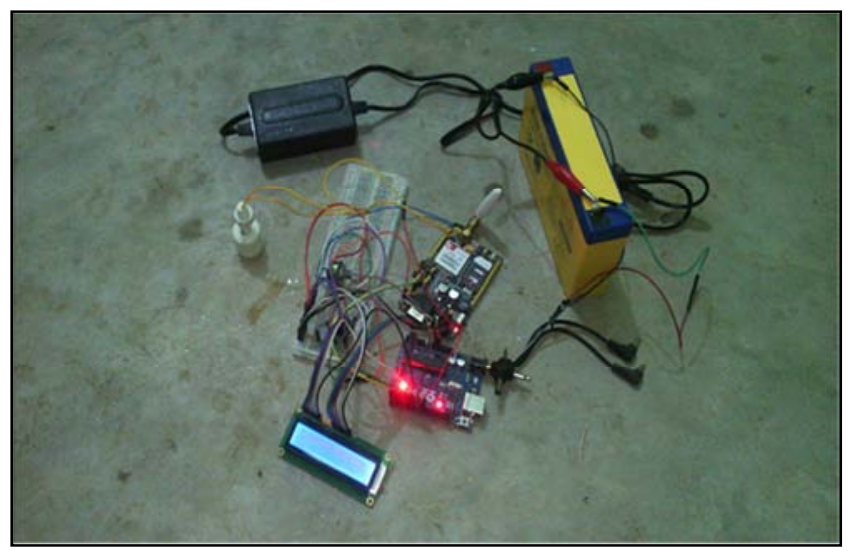

Figure 17. All elements Demonstration (assemble).

\subsection{Feedback of Local Respondents After Demonstrative Implementation of the Device}

Awareness raising and training program that was conducted during this research were willingly attended by the local people and regional governing bodies which itself is a great response for the use of mobile services in early warning communication.

Local respondents expressed they will be more benefited if development of a Voice based services implementation is possible in the warning communication system as messages are more likely to be not understood by the end users as most of them are illustrate.

The NGO officials present during the demonstration of the system suggested Text based messages (SMS) should use symbols, local measuring units and refer to other sources for further information.

Local governing bodies expressed their willingness to organize public awareness programs and training programs if these kinds of warning systems are implemented in their areas.

NGO personals will enhance awareness raising and training efforts with regards to preparedness and response to this kind of early warning systems.

Locals also suggested that loud speakers in mosques can be used around the area to spread the warning provided by the devices.

Some of the respondents who had a good educational background were expressing their will to conduct awareness programs based on the warning system.

They also expressed their financial difficulties to locally implement such a warning system as they look forward to the stakeholders and governing bodies to patronize for these kinds of technological development in flash flood warning.

Locals also inquired if the system is able to measure the actual gratitude of the flash flood.

Some of the less educated respondents were not convinced that this device can actually provide warning on a consistent basis.

Locals addressed their lack of knowledge over English, so they insisted on the SMS to be in Bangla so they can understand better.

Community-based early warning systems must be better implemented to achieve the desired risk mitigation through.

EFWS Suggested the experts.

Locals demanded community-based information Centre for estimation of the loss caused by flash floods. so they can identify the difference in the magnitude of economical and personal loss before and after the implementation of the warning system.

\section{Conclusion}

The North-Eastern region of Bangladesh, normally first flash flood occurs between middle of April to end of April. This interdisciplinary study has demonstrated the present flash flood early warning system in the north-eastern parts of 
Bangladesh and worked for designing and implementing new and innovative crowd sourcing based FFEWS. So, it is very essential to develop a warning system for their better life and as well as to reduce some damage. A warning of a flood event implies an existing threat of danger to life and property, and it invites responsive action to reduce threat. This plan is to meet the expectation to develop the device and its implementation. But its strongly believed that this demo device is not very effective in the area. More developed technology should be invented to cover more area. Government should raise more funds to conduct this type of research. That is also important to develop this country. Besides government should take necessary steps and should arrange proper training programs to make people aware about flash flood.

\section{Acknowledgements}

The authors received funding for this research work from Research and Scholarship Branch, Ministry of Information and Communication Technology, Government Republic of Bangladesh and the work is also supported by Department of Environmental Science and Management, North South University, Dhaka, Bangladesh. Authors are grateful to the staffs, students and teachers of these organizations.

\section{References}

[1] BBS, B B O S., Statistical Yearbook of Bangladesh. Statistics Division, Ministry of Planning, Dhaka, Government of the People's Republic of Bangladesh, 2011.

[2] Fakhruddin, S., Applications of medium range probabilistic flood forecast for societal benefits: Lessons learnt from Bangladesh, in Reducing disaster: Early warning systems for climate change. 2014, Springer. p. 167-183.

[3] Huq, S. and G. Rabbani, Climate change and Bangladesh: policy and institutional development to reduce vulnerability. Journal of Bangladesh Studies, 2011. 13(1): p. 1-10.
[4] Alam, J., Concept of flood shelter and its planning to cope with flood. Village Infrastructure to Cope with the Environment, Dhaka and Exeter, November, 2000.

[5] Chowdhury, M R., An assessment of flood forecasting in Bangladesh: the experience of the 1998 flood. Natural hazards, 2000. 22(2): p. 139-163.

[6] Moges, A., Flood forecasting and early warning system (FFEWS) an alternative technology for flood management system and damage reduction in Ethiopia.

[7] Uddin, M R. and M. A. Awal, Early warning on disastrous weather through cell phone. IOSR Journal of Computer Engineering, 2013. 11: p. 51-53.

[8] Rahman, M M., M. A. Hossain, and A. K. Bhattacharya. Flood management in the flood plain of Bangladesh. in International Conference on Civil Engineering in the New Millennium: Opportunities and Challenges (CENM). 2007.

[9] Hossain, A. An overview on impacts of flood in Bangladesh and options for mitigation. in national workshop on options for flood risk and damage reduction in Bangladesh. 2004.

[10] Mosley, P. and D. Hulme, Finance Against Poverty: Volume 2: Country Case Studies. 2006: Routledge.

[11] Basher, R., Global early warning systems for natural hazards: systematic and people-centred. Philosophical Transactions of the Royal Society of London A: Mathematical, Physical and Engineering Sciences, 2006. 364(1845): p. 2167-2182.

[12] Handmer, J., Improving flood warnings in Europe: a research and policy agenda. Global Environmental Change Part B: Environmental Hazards, 2001. 3(1): p. 19-28.

[13] BTRC., Bangladesh Telecommunication Regulatory Commission, 2014.

[14] Bela, G. and Liptak (ed.), Instrument Engineers' Handbook, Fourth Edition, Volume One: Process Measurement and Analysis, CRC Press, 2003, ISBN 1420064029 page 477.

[15] David, L., Thomas, B. and Reddy (ed.), Handbook of Batteries 3rd Edition. McGraw-Hill, New York, 2002 ISBN 007-135978-8 chapter 22. 